\title{
Empowering the Transient Poor ---An Alternative Strategy for Poverty Eradication in Indonesia
}

\author{
Djonet Santoso \\ Doctorate Student: Faculty of Social and Political Sciences \\ Universitas Diponegoro \\ Semarang, Indonesia \\ (djonetsantoso@yahoo.com)
}

\author{
Sri Suwitri \\ Faculty of Social and Political Sciences \\ Universitas Diponegoro \\ Semarang, Indonesia \\ (sri_suwitri@yahoo.co.id)
}

\begin{abstract}
Poverty reduction policies in Indonesia are primarily informed by periodic cross-section household survey data that provide estimates of static poverty rates. The focus of these policies appears to be chronic or long-term poverty. While estimates of poverty at specific points in time might correlate with chronic poverty to some extent, such estimates are more representative of poverty that is transient in nature. However, the characteristics of transient poverty is a relatively underexplored area of research. If the determinants of transient and chronic poverty are quite different, then different policy measures would be required to address these two aspects of poverty. An understanding of common characteristics, on the other hand, could point to poverty reduction strategies that apply to both poverty types. This paper point to neglected focus on transient poverty, need for a new poverty eradication strategy, and strategic programs and activities should be covered.
\end{abstract}

\section{Keywords—transient poverty; social welfare}

\section{INTRODUCTION}

There have been many policies for poverty reduction prepared by the government and has also been implemented. The fundamental issue is that these policies actually increase the number of poor people with the entry of transient poor into it. Although in much of the literature and the discussion touched upon on transient poverty, but not much found in deep discussion about the determinants of transient poverty. A lot of discussion about the determinants of poverty that is more directed at very poor understanding or chronic poverty. In line with this, study on the transient poverty and its role on poverty eradication becomes important and very strategic to solve other problems of poverty that has not been touched. The study is expected to provide a new perspective for poverty eradication program by giving more attention to the transient poor.

\section{Transient Poverty Overview}

To determine the presence of transient poor communities, results of three surveys conducted by Central Bureau of Statistics that are PSE-05 (Socioeconomic Data Collection 2005), PPLS-08 (Social Protection Program Data Collection 2008), and PPLS 2011 (Social Protection Program Data Collection 2011) can be presented in Table 1 as follows:
TABLE: COMPARISON CATEGORY OF POOR HOUSEHOLDS IN THREE SURVEYS OF PSE-05, PPLS-08, AND PPLS 2011

\begin{tabular}{|l|c|c|c|c|c|}
\hline \multirow{2}{*}{ Category } & PSE-05 & \multicolumn{2}{|c|}{ PPLS-08 } & \multicolumn{2}{c|}{ PPLS-2011 } \\
\cline { 2 - 7 } & $\begin{array}{c}\text { House- } \\
\text { hold } \\
(\%)\end{array}$ & $\begin{array}{c}\text { House- } \\
\text { hold } \\
(\%)\end{array}$ & $\begin{array}{c}\text { Household } \\
\text { member }\end{array}$ & $\begin{array}{c}\text { House- } \\
\text { hold } \\
(\%)\end{array}$ & $\begin{array}{c}\text { Household } \\
\text { member }\end{array}$ \\
\hline Extremly & 20,4 & 17,1 & 15.944 .536 & 16,3 & 16.003996 \\
\hline Poor & 43,1 & 39,1 & 25.190 .010 & 17,3 & 14.300 .683 \\
\hline Nearly poor & 36,5 & 43,8 & 19.261 .505 & 33,2 & 24.004 .988 \\
\hline Vulnerable & - & - & - & 33,2 & 21.177 .500 \\
\hline Total & 100 & 100 & 60.396 .501 & 100 & 75.478 .167 \\
\hline
\end{tabular}

(Source: Research results, data processed, 2015)

In PSE-05 and PPLS-08, data collection focuses only on the category of very poor households, poor and nearly poor. The dynamics in the field encourage PPLS-2011, which adds the category of Vulnerable poor Households. Referring to the categorization of the poor and the development of data collection, it can be noted that the existence of transient poor population can be demonstrated by the number of households and the number of household members of Extremly Poor, Poor, Nearly Poor, and Vulnerable. The number of Nearly Poor Households increase from 36.5 on the calculation of PSE-05 to 43.8 percent on the calculation of PPLS-08, but experincing decreased to 33.2 percent on the calculation of PPLS-2011. It is interesting to note that although the percentage is decreasing, the number of Nearly Poor Households members increased from about 19.2 million people on the calculation PPLS-08 to an estimated of 24 million people on the calculation PPLS2011. This shows that the absolute number of people in the Nearly Poor category increases. If the number of population of Nearly Poor and Vulnerable Poor united in a single category of transient poor, then according to calculations of PPLS-2011 the numbers are very large, which is about 45.2 million people or 66.4 percent.

\section{Poverty Reduction InTERVENTION IN INDONESIA}

Poverty reduction efforts by the Government of Indonesia (GOI) have evolved since the 1970s. Change was driven not only by internal dynamics but also foreign factors such as the International Monetary Fund (IMF) and foreign investors. In the 1970s the GOI adopted the basic-needs approach to alleviate poverty. This was reflected by the establishment of the poverty line at 2100 calories of intake per capita per day. It defined the five main basic needs for people to survive and live in dignity as food, health, water and sanitation, education, and shelter. The approach aimed to eradicate hunger, disease and 
illiteracy despite scarce resources by targeting the 40 percent poorest of the population. This approach addressed the issue of poverty rather than income levels. However, this basic-needs approach caused considerable issues as it tended to ignore the complexity of poverty, which was the result of poor human resources, lack of social infrastructure, and problems in natural resource management.

Two decades after applying the basic-needs approach, a new approach namely the empowerment approach, came into picture. Critical aspect of the empowerment agenda was to reduce inequality by broadening human capabilities through universal basic education, health care, and social protection. It also sought distribution of tangible assets such as land or access to capital. Empowerment also meant more participatory and bottom up development objectives, aimed to enhance policy effectiveness at the local level in terms of design, implementation, and outcomes. This approach also concentrated on improving governance as well as innovation and experimentation by both public and private actors to develop pro-poor institutional mechanisms.

To address the challenges, and fulfill its commitments to the achievement of the MDGs, the Indonesian government developed a set of policies and programs in its Medium-Term Development Plan 2004-2009 and 2009-2014, putting emphasis on the social services including education, health and family planning, and community services for the empowerment and protection of the poor and vulnerable groups. The Plan envisages to address poverty in three clusters of poverty alleviation programs. The first cluster is the social welfare and social protection program, directed to poor households to help them meet the minimum level of their basic needs. The program within this cluster would be rice subsidies, health services for the poor, education for poor students, cash transfers, especially Conditional Cash Transfers (CCTs) to help poor households facing the economic shocks, etc. The second cluster is the empowerment program which is now is embraced by the Program Nasional Pemberdayaan Masyarakat (PNPM)Mandiri (National Program for Community Empowerment); and the third cluster would be the micro and small enterprise programs which includes assistances for micro enterprise, and also subsidy for small credit etc.

\section{EMPOWERING THE TRANSIENT PoOR}

The economic crisis that has taken place in Indonesia since 1997 coupled with a global economic recession since mid 2008 has brought the impact of broad implications. One of them related to poverty is the increasing number of poor people significantly. This encourages the emergence of a new reality in Indonesia, namely the presence of transient poverty group in large numbers. The term transient poverty is used to designate or describe groups of people who fall into the classification of nearly poor and vulnerable poor (BPS 2015), or groups of people who are slightly above the poverty line (Bappenas 2006). They are groups of people who are not poor but its position at slightly above the poverty line, so they do not get subsidies from the many government programs for poverty reduction. This group is highly susceptible to various changes that occur in the surrounding environment. Policy to raise the price of fuel with many variants for example, would trigger inflation that are negative towards the welfare of society as it affects the real income. It is clear that policy to raise fuel prices lead to increase the number of poor people because of the declining of purchasing power of the near poor. It happened because of rising fuel prices certainly be followed by price increases in any other subjects that would trigger a negative inflation.

From the discussions, it is recommends an innovative community empowerment model of transient poor. The draft model developed in this study is presented in the figure. In the model, the empowerment of the group of transient poor (TP), reinforced by social empowerment, economic empowerment, and public policy support. In the early stages, the strengthening of social capital necessary to transient poor people through a process of reflection, social mapping, strengthening the capacity of survival, and capacity building. The concept of social capital can be categorized into two groups. The first group emphasizes on the network of social relationships (social networks), while the second group put more emphasis on the characteristics (traits) that are attached (embedded) in the individual human being involved in a social interaction. The next stage of the transient poor group empowerment is economic empowerment. Economic empowerment in the model develops more focus on channeling activity that is building partnerships with other group of people, government sectors, private sectors, financial institutions to generate their economic activity. Channeling is a form of activity aimed at encouraging partnerships between the transient poor with other parties (private/government/ institution concerned) in order to maintain their economic survival skills and will continue to be developed and to be well-established economic group. In this point, there should be a strong commitment from all parties to set off widest opportunities and actively encourage the transient poor community group to be able to access the economic potential resources. The most important part of the application of this model is the concern, commitment, and seriousness of the central government as well as local government through its public policy to consent to the existence of transient poor and significantly assign more attention to the transient poor. Just as the chronic poor, the existence of transient poor group is also the responsibility of the government.

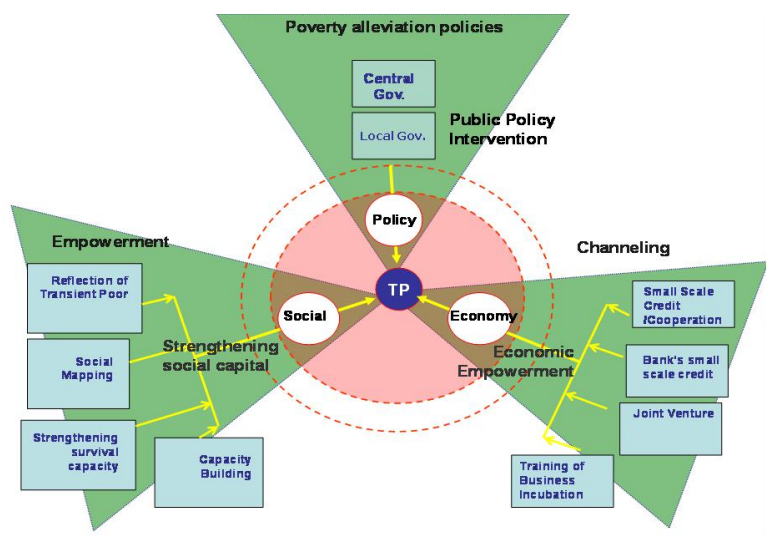

Figure: Empowerment model of transient poor 


\section{CONCLUDING REMARKS}

There are three public policy priorities to maintain the position of the transient poor communities. First, as it grows, the economy in general is being transformed from an economy that relies on the traditional agricultural sector into the economy that will rely more on services and industrial sectors. Priority to make growth work for the transient poor are more friendly investment climate in urban areas, particularly through the development of a better urban development. Second, in line with the strengthening of democracy and the implementation of decentralization, change of service provider largely by central government to local governments to make more beneficial services for the near poor. Accordingly, the priority is increasing the capacity of local government and better incentives for the provision of services. Third, the priorities for making public expenditure work for the transient poor is to shift from intervening in the market for commodities which are consumed by most people (such as fuel and rice) into the targeted income support to poor households, and use the fiscal space to improve the strategic service such as education, health, clean water and sanitation. Significantly, empowering the transient poor, I believe could be an innovative alternative strategy for poverty eradication in Indonesia.

\section{REFERENCES}

[1] National Development Planning Board, Badan Perencanaan Pembangunan Nasional (Bappenas). 2006. "Potensi Transient Poverty di Indonesia Tahun 2005". Majalah Info Kajian Bappenas Vol.3 - No.1 Oktober 2006, hal 26-31.

[2] Central Statistics Board, Badan Pusat Statistik (BPS). 2015. Penghitungan dan Analisis Makro Kemiskinan Indonesia Tahun 2014. Jakarta: CV. Nario Sari. 